\author{
Dominika Hotuj \\ Katedra Historii Gospodarczej i Społecznej \\ Uniwersytet Ekonomiczny w Krakowie
}

\title{
Ekonomiczno-społeczne uwarunkowania efektywności procesów dostosowania struktur samorządowych do zasięgu obszarów funkcjonalnych na przykładzie Krakowa początków XX wieku
}

\section{Streszczenie}

W artykule dokonano analizy uwarunkowań przeprowadzania procesów dostosowania gminnych struktur samorządowych do wymagań rosnącego obszaru zurbanizowanego wokół Krakowa z początków XX w. W objętych badaniem źródłach historycznych poszukiwano odpowiedzi na pytanie o determinanty sukcesu tego procesu. Porównano też ówczesną i obecną sytuację samorządów tworzących obszar funkcjonalny, stwierdzając z jednej strony wyraźne analogie, z drugiej zaś pewne zróżnicowanie sytuacji z początków wieku i współczesnej. Różnice te, wynikające z występującej obecnie większej zamożności gmin ościennych, wyższego poziomu wartości tożsamości lokalnej, spektakularnych sukcesów samorządów gminnych np. w polityce inwestycyjnej czy pozyskiwaniu inwestorów strategicznych, każą sądzić, że konieczny do przeprowadzenia w przyszłości proces dostosowawczy będzie niezwykle trudny do implementacji w formie zapewniającej efektywność jego działania.

Słowa kluczowe: obszary funkcjonalne, obszary metropolitalne, Kraków, samorząd miejski. 


\section{Wstęp}

Jednostki samorządu terytorialnego są ograniczone zasięgiem oddziaływania do ustalonych administracyjnie granic, zaś rzeczywistość społeczno-gospodarcza tworzy powiązania funkcjonalno-przestrzenne, które mogą znacząco odbiegać od tych sztywnych podziałów. Taka sytuacja występuje zwłaszcza na obszarach silnie zurbanizowanych, w tym metropolitalnych. Stanowiący funkcjonalną całość teren jest pokryty siatką gmin, z których każda ma określone priorytety rozwojowe oraz założenia polityki lokalnej, w tym finansowej. Każda jest świadoma swojej roli w systemie funkcjonalnym, kosztów i korzyści, które z niej wynikają. Ich bilans dla danej jednostki we wzajemnych interakcjach występujących w obszarze funkcjonalnym kreuje określoną postawę wobec jednostek sąsiednich, w szczególności zaś jednostki rdzeniowej. Samorządy lokalne są podmiotami autonomicznymi, działającymi samodzielnie jako elementy systemu funkcjonalnego, skazane na działanie w niedoskonałych w wielu wymiarach granicach. Wobec takich okoliczności i w powiązaniu z indywidualnym wynikiem bilansu przewag konkurencyjnych w ramach obszaru funkcjonalnego mogą one dążyć do współpracy z innymi jednostkami lub też izolować się od nich, wykorzystując przewagi komparatywne wynikające z posiadanych zasobów oraz faktu lokalizacji w większej całości przestrzenno-funkcjonalnej, jaką jest obszar metropolitalny.

Polskie wielkie miasta znajdują się obecnie w sytuacji prawno-politycznej, która narzuca granice, zadania, kompetencje, pozostawiając jednak wciąż niedokończone dzieło kreacji systemu w związku z brakiem istnienia szczegółowych rozwiązań dotyczących funkcjonowania obszarów metropolitalnych. W lipcu 2013 r. przyjęte zostały wprawdzie „Założenia krajowej polityki miejskiej do roku 2020", dające nadzieję na szybkie stworzenie na ich bazie dokumentu, który ma szanse zmienić realia funkcjonowania samorządów wielkich miast i ich otoczenia, jak jednak wskazują zapisy jego założeń (s. 17), jednym z celów przygotowywanej polityki będzie stworzenie warunków do skutecznego, efektywnego i partnerskiego zarządzania rozwojem w obszarach metropolitalnych. Rozwiązania legislacyjne nie dadzą więc gotowego przepisu na uzyskanie takich cech współpracy, stworzą jedynie jej prawno-organizacyjne ramy, ujęte w schemat działania odrębnej, nowej grupy gmin tzw. metropolitalnych, czy też po prostu bardziej sformalizowanych i umocowanych kompetencyjnie i finansowo struktur administracyjnych złożonych z kilku lub kilkunastu dotychczasowych jednostek samorządu terytorialnego. W trwającej od wielu lat dyskusji nad wprowadzeniem tych zmian prace skupiają się szczególnie na dwóch aspektach: wyborze formy organizacyjnej oraz ustaleniu wytycznych do wskazania granic administracyjnych obszarów (pierwszy krok w tym kierunku poczyniono w „Koncepcji przestrzennego zagospodarowania kraju 2030", s. 21 i dalsze). Te dwa problemy stanowią 
główne osie dyskusji, zaś ich podłoże wynika z wzajemnych oddziaływań i oczekiwań elementów składowych układu, czyli poszczególnych gmin. W rozważaniach tych często umykają jednak kwestie kluczowe, dotyczące już nie samego ustalania zasad tworzenia tych nowych struktur i administracyjnych reguł ich egzystencji. Najważniejszym sprawdzianem nadchodzącej zmiany będzie bowiem nie tyle implementacja, ile efektywność i skuteczność jej działania. Determinanty osiągania tych cech wydają się niezależne od przyjętych rozwiązań legislacyjnych. Nawet zmuszenie samorządów do współpracy (np. poprzez odgórne, centralne wyznaczenie zakresu terytorialnego i kompetencyjnego nowych struktur) nie będzie bowiem gwarantem jakości działania. Analizując rozliczne przykłady efektywności funkcjonowania proponowanych rozwiązań, można zauważyć, że główną jej determinantą są właśnie wzajemne oczekiwania i wynikające z nich postawy przedstawicieli jednostek administracyjnych mających stworzyć lub tworzących strukturę samorządową w ramach obszaru funkcjonalnego [Slack 2007]. Dlatego też szczególnie istotne wydaje się obecnie poznanie determinant powodzenia, jakości, efektywności podejmowanych prób współpracy czy też barier ich implementacji. W toczącej się w Polsce dyskusji przywoływane są przykłady już stworzonych koncepcji zarządzania obszarami metropolitalnymi w krajach europejskich czy szerzej - na świecie i wskazuje się na konieczność dokończenia procesu decentralizacji państwa (zob. m.in. [Smętkowski i Jałowiecki, Gorzelak 2008, „Zielona księga...” 2012, „Biała księga...” 2013, Izdebski 2012, Bober i in. 2013]. Rzadziej wzorców do naśladowania poszukuje się w historii polskich miast i procesach ich przestrzennego rozwoju, pomimo że w ostatnich 100 latach liczne ośrodki przechodziły z sukcesem przez trudny proces rozszerzania granic. Dlatego też w niniejszym artykule postanowiono dokonać analizy jednego z takich procesów rozszerzenia, który (pomimo wielu trudności na etapie negocjacji, jak również przestrzenno-funkcjonalnego scalania już w ramach rozszerzonych granic) rysuje obraz rozmaitych płaszczyzn interakcji pomiędzy gminami. Ich podłoże w znacznej większości przypadków opiera się na uwarunkowaniach ekonomiczno-społecznych.

Przedmiotem analizy jest Kraków u progu XX w., którego władze w rezultacie wieloletnich negocjacji z gminami sąsiednimi doprowadziły do powstania tzw. Wielkiego Krakowa. Sięgnięto tym samym do bogatego źródła wiedzy w zakresie trudności procesów dostosowawczych. Przykład ten jest odległy w czasie, dotyczy odmiennych realiów politycznych i gospodarczych, jednak w warstwie analitycznej interakcji pomiędzy różnymi jednostkami tworzącymi obszar metropolitalny dostarcza wciąż aktualnych informacji, wniosków i refleksji. Stąd też celem artykułu jest usystematyzowanie okoliczności determinujących skuteczność procesów dostosowawczych struktur administracyjnych do układów funkcjonalnych oraz porównanie tych okoliczności z początków wieku i istniejących obecnie. 
Zaznaczyć należy, że proces przebiegający wiek temu dotyczył włączania dawnych gmin w struktury administracyjne miasta rdzeniowego ${ }^{1}$. Dzisiejsze działania to raczej poszukiwanie drogi współpracy opartej na nowym szczeblu samorządu lub też nowej sformalizowanej formy współpracy. Zawsze jednak najważniejszym celem procesu było doprowadzenie do sytuacji, w której administrowanie będzie bardziej efektywne i racjonalne z perspektywy obszaru jako całości.

\section{Ekonomiczno-społeczne uwarunkowania efektywności procesu negocjacji pomiędzy Krakowem a gminami sąsiednimi w latach 1910-1915}

Jak wspomniano, największym problemem w tworzeniu Wielkiego Krakowa było wypracowanie kompromisowych warunków włączenia gmin w nowe struktury administracyjne. Przebieg tych negocjacji, zapisany w historycznych dokumentach, pozwala na nakreślenie następujących przyczyn i zależności, które determinowały postawę gminy sąsiadującej z Krakowem wobec włączenia w struktury miasta oraz okoliczności, które w wyniku działania partykularnych interesów wraz z upływem czasu zwiększały koszt konsolidacji.

1. Gminy o niskich dochodach, małym potencjale ludnościowym i gospodarczym, głównie o charakterze wiejskim, wykazywały silną chęć włączenia w struktury miasta rdzeniowego. Podobne postawy wykazywały gminy bezpośrednio sąsiadujące z Krakowem, o miejskim stylu zabudowy, ale jednocześnie niedysponujące środkami finansowymi na konieczne inwestycje. Ponieważ nie mogły one samodzielnie realizować ważnych zadań, w przyłączeniu widziały szansę na poprawę tego stanu. Utrata samodzielności zostałaby zrekompensowana także poprzez możliwość korzystania z licznych prywatnych zapisów i fundacji, które mogły być wykorzystane na różne rodzaje pomocy społecznej, jednak jedynie dla mieszkańców miasta [„,Sprawozdanie Komisji Gminnej...” 1908]. Przyłączenie do Krakowa dawało nowym mieszkańcom dostęp do tych środków. W takich okolicznościach koszt włączenia w struktury miasta był stosunkowo łatwy do zaakceptowania, choć dodać należy, że gminy wykazujące chęć przyłączenia do Krakowa określiły także szereg warunków, od których uzależniona była ich ostateczna zgoda - były wśród nich często liczne inwestycje, które przybliżyłyby komfort zamieszkania i funkcjonowania do tego, jaki istniał w Krakowie (m.in. w zakresie oświetlenia, uporządkowania i wybrukowania ulic, zbudowania systemu kanalizacji i wodociągów, chodników). Takie właśnie postulaty jako

${ }^{1}$ Rozwiązywanie kwestii rozbieżności struktur funkcjonalno-przestrzennych w stosunku do granic administracyjnych miast przełomu wieków XIX i XX przeprowadzane było w formie włączeń w struktury miasta rdzeniowego, co dotyczyło także Pragi i Wiednia. 
warunki przyłączenia pojawiały się m.in. w protokołach z posiedzeń rad gminnych $^{2}$ Ludwinowa, Dębnik czy Półwsia Zwierzynieckiego [1904]. Nieco odmienne oczekiwania miały gminy o charakterze wiejskim, gdzie dążono do zachowania możliwości prowadzenia działalności rolniczej, ale także wymagano rozwoju sieci szkół powszechnych [„Protokół z posiedzenia Rady Gminnej w Łobzowie” 1904].

Zaznaczyć należy, że gminy oczekujące dużych nakładów finansowych ze strony Krakowa często zastrzegały także w protokołach negocjacji określone okresy karencji dla zwiększonych obciążeń podatkowych i innych (np. podatek spożywczy, opłaty za korzystanie z wodociągów), związanych z objęciem terenów włączonych przepisami, które obowiązywały w Krakowie.

2. Gminy, które rozwijały swoją zabudowę, korzystając z różnic w cenach nieruchomości i koszcie życia w stosunku do Krakowa, były trudnymi negocjatorami, ponieważ włączenie w struktury miasta niwelowało te przewagi. Istotnym czynnikiem wpływającym na rozwój budownictwa na obrzeżach Krakowa były też mniejsze wymagania dotyczące form i jakości wznoszonych budynków. Przykłady takich obszarów to Nowa Wieś Narodowa czy Krowodrza, które w swojej zabudowie przypominały krakowską, jednak ustępowały jej jakościowo. Ludzie migrujący z Galicji do Krakowa, jak również niektórzy spośród dotychczasowych krakowian przenosili się na tereny gmin sąsiadujących z miastem, co pozwalało na korzystanie z dobrodziejstw sąsiedztwa przy znacznie mniejszym koszcie życia. Zróżnicowanie wysokości czynszów w Krakowie i gminach sąsiednich było bardzo duże i przedstawiało się następująco: podczas gdy w Krakowie od 2068 domów w 1902 r. płacono łącznie 8124761 koron, od 1975 domów w gminach przyłączonych do 1901 r. płacono jedynie 1339374 korony [Studya... 1905, tablica XXI].

Analogiczna prawidłowość - zjawiska wymywania - dotyczyła podmiotów gospodarczych. W roku 1902 w Krakowie działało 86 zakładów przemysłowych, zaś w gminach sąsiednich aż 88, z czego 39 w samym Podgórzu [Przeorski 1931, s. 206-208 oraz Studya... 1905, s. 17]. Podmioty zyskiwały dzięki tej lokalizacji tańsze nieruchomości, siłę roboczą, niższe obciążenia podatkami i opłatami oraz łatwiejszy dostęp do naturalnych zasobów (np. gliny, wapna). Proces rozlewania się zabudowy powodował więc, że coraz większy potencjał ówczesnego obszaru funkcjonalnego znajdował się poza miastem. Stan ten mógł ulec dodatkowemu pogorszeniu w przypadku realizacji planów budowy kanału Kraków-Wiedeń, gdyż zakładano jego lokalizację w obszarze poza granicami miasta [Studya... 1905, s. 23-24].

${ }^{2}$ Postanowienia zawarte w protokołach posiedzeń rad gminnych były w znakomitej większości w analogicznej formie powtarzane w finalizujących proces rozwoju przestrzennego Krakowa umowach o przyłączenie. 
Odpływ kluczowych podmiotów gospodarczych z miasta skutkował nie tylko bezpośrednimi stratami w odprowadzanych przez nie podatkach i opłatach. Towary były również tańsze od wytwarzanych w Krakowie, choć bardzo często jednocześnie o gorszej jakości [„,Sprawozdanie Wydziału Krajowego...” 1907].

3. Gminy zagospodarowywały swoją przestrzeń zgodnie z indywidualnymi potrzebami, a nie w sposób, który zapewniał racjonalność całego systemu funkcjonalno-przestrzennego. Rozrastająca się zabudowa w obszarach podmiejskich wraz z upływem czasu zmniejszała efektywność przyszłych działań zmierzających do ujednolicenia standardów zagospodarowania przestrzeni w nowych granicach. Niska była jakość tej zabudowy, zaś sposób jej rozplanowania w przestrzeni odzwierciedlał istniejące układy przestrzenne typu wiejskiego lub podmiejskiego, które po włączeniu do miasta mogły być przeobrażone tylko częściowo i dużym nakładem kosztów. Zjawisko przybierało dodatkowo na sile w obszarach, dla których znoszono rewersy demolacyjne ${ }^{3}$ [,Sprawozdanie Wydziału Krajowego...” 1907].

4. Upływ czasu niekorzystnie oddziaływał także na finanse przyszłego wielkiego miasta. Każda z gmin w swojej polityce finansowej kierowała się własnymi, partykularnymi interesami, w tym w zakresie celów, na jakie zaciągano tytuły dłużne. Niekiedy ze zwrotnych środków zewnętrznych pokrywano koszt budowy infrastruktury, która albo byłaby znacząco tańsza, jeżeli realizowano by ją od razu na większym obszarze, albo stawała się zbędna po włączeniu do Krakowa (z uwagi na fakt, że miasto już nią dysponowało) [Studya... 1905, s. 29]. Tym samym zadłużano budżety, a zadłużenie to (czasem nieuzasadnione ekonomicznie) musiał przejąć Kraków w chwili włączenia gminy w swoje struktury. Sytuacja ta dotyczyła takich inwestycji jak: budowa rzeźni, elektrowni, gazowni.

5. W powiązaniu z poprzednią obserwacją trzeba dodać, że w sytuacji przed włączeniem gmin sąsiednich miasto rdzeniowe ze względów społecznych (np. zdrowotnych) zmuszone było ponosić szereg wydatków, które związane były z działaniami poza jego granicami. Przykładem mogą być usługi straży pożarnej czy Towarzystwa Ratunkowego. Ze względów epidemiologicznych Kraków wysyłał także swoich rakarzy do sąsiednich gmin, aby móc skutecznie walczyć z wścieklizną. Chroniono więc od zarazy zarówno rdzeń, jak i jego otoczenie, a koszt tej ochrony pokrywał tylko Kraków [Studya... 1905, s. 14-15, 20]. Niwelowano skutki zaniedbań sanitarnych w sąsiednich gminach (np. na koszt Krakowa wybudowano podziemny kanał odprowadzający ścieki w gminie Grzegórzki, ponieważ zastosowane tam rozwiązanie powierzchniowego ich odprowadzania

\footnotetext{
${ }^{3}$ Ustalenie dla danego obszaru rewersów demolacyjnych oznaczało wprowadzenie niemal pełnych ograniczeń w zabudowie. Inwestor, wznosząc budynek, podejmował ryzyko konieczności dokonania jego rozbiórki na każdorazowe wezwanie władz zaborczych. Rozbiórkę wykonywano w takiej sytuacji na koszt właściciela nieruchomości.
} 
powodowało zagrożenie epidemiologiczne oraz fetor zatruwający powietrze w Krakowie) [Bąkowski 1905]. Niekiedy mieszkańcy okolicznych gmin korzystali z usług na terenie miasta, ponieważ były one na wyższym poziomie (np. szkolnictwo powszechne - w roku szkolnym 1902/1903 do szkół w Krakowie uczęszczało 360 uczniów zamieszkałych w gminach podmiejskich) [Studya... 1905, s. 20]. Aby zachować pełny obraz sytuacji, trzeba jednak zaznaczyć, że sąsiedztwo terenów zabudowanych generowało w przypadku niektórych usług obopólne korzyści. Kraków sprzedawał usługi komunalne, a sąsiednie gminy nie musiały ponosić kosztu ich wprowadzenia (i tym samym nieracjonalnie pod względem efektywności gospodarowania się zadłużać - co opisano wcześniej).

6. Rozpatrując szereg czynników natury ekonomicznej, powinno się także uzupełnić ten katalog o współzależne z nimi czynniki społeczno-polityczne. Proces rozszerzania granic miast pociągał bowiem za sobą także i tego rodzaju konsekwencje. Zmianie ulegał status dotychczasowej ludności wiejskiej - osoby te stawały się „nowymi mieszczanami”. Nie zawsze jednak proces ten odbierany był jako nobilitacja. Wielu dotychczasowych wpływowych obywateli gmin podmiejskich obawiało się włączenia do Krakowa. Dr Klemens Bąkowski w Sprawie rozszerzenia granic Krakowa napisał: „Wielkości małomiejskie boją się zejścia z piedestału i utonienia w tłumie obywateli wielkiego miasta" [1905, s. 7]. O ile osoby te nie zawsze miały szansę ochrony dotychczasowego statusu społecznego, o tyle władze gmin podmiejskich dobrze zabezpieczyły swój przyszły los w rozszerzonym mieście w formie odpowiednich zapisów w protokołach negocjacyjnych. Protokoły te wielokrotnie wskazują konkretne wymagania związane z zakresem reprezentacji oraz utrzymania określonych stanowisk urzędniczych, nieraz ze wskazaniem wymagań płacowych (zob. np. protokoły z posiedzenia rad gminnych w: Łobzowie [1904], Dębnikach [1904], Zakrzówku [1904], Dąbiu [1905]).

Podczas gdy ambicje władz słabszych ekonomicznie gmin podmiejskich mogły być zaspokojone wskazanymi ustaleniami, w przypadku włączenia Podgórza sytuacja była dużo trudniejsza z uwagi na ogromny i rozwojowy potencjał miasta. Władzom Podgórza trudno było się pogodzić z utratą suwerenności, co znacząco utrudniało lub momentami uniemożliwiało postęp procesów negocjacyjnych. Interesujące porównanie stosunku, jaki względem Krakowa reprezentowały władze Podgórza, dał K. Bąkowski, który przybliżył kwestię wysłania przez krakowski magistrat wniosku o rozpoczęcie negocjacji w sprawie włączenia Radzie Miasta Podgórze. Rada ta zareagowała silnie emocjonalnie na okoliczność wystąpienia z takim wnioskiem nie bezpośrednio przez Radę Miasta Krakowa, ale jedynie przez struktury urzędowe. Oddając panujące ówcześnie emocje pomiędzy miastami, K. Bąkowski napisał: „(...) w Podgórzu obowiązuje hiszpańska etykieta i grandowie podgórscy nie mogą odpowiadać magistratowi krakowskiemu, póki kortezy krakowskie o to ich nie poproszą" [1905, s. 11]. Podgórze utrudniało także 
dostęp do danych finansowych gminy, jakich krakowski magistrat potrzebował do analizy skutków powiększenia terytorium miasta [Bąkowski 1905, s. 44]. Ten negatywny stosunek do przyłączenia wynikał z wysokiego poziomu rozwoju samego miasta, jak również jego infrastruktury miejskiej. Jednostka - jako jedyna z grupy gmin sąsiednich - posiadała własną straż ogniową, personel sanitarny, szpital, brukowane ulice itd. [Studya... 1905, s. 72-74, 80-81; „Sprawozdanie Komisyi Rady Miasta Podgórza...” 1913]. W największym też stopniu posiadała ona wiedzę na temat przyszłych trudności, jakie trzeba będzie przezwyciężyć, aby Wielki Kraków stał się faktycznie miejską całością, spójną w wymiarze przestrzennym, funkcjonalnym, ekonomicznym i społecznym. Władze Podgórza, broniąc się przed włączeniem, wiedziały, że będzie ono wymagało wieloletnich inwestycji. Funkcjonując w korzystnych dla siebie uwarunkowaniach lokalizacyjnych i finansowych, nie chciało stać się drugą po Krakowie jednostką samorządową, na której barkach spocznie wielowymiarowa asymilacja nowych obszarów.

7. Całości obrazu wzajemnych stosunków pomiędzy społecznością krakowską a społecznościami gmin sąsiednich dopełniają obawy związane z oczekiwanym pojawieniem się zjawisk społecznie niepożądanych. O ile mieszkańcy Krakowa obawiali się zwiększenia poziomu przestępczości (z uwagi na doniesienia o bójkach, rabunkach na terenach podmiejskich), o tyle dla części społeczności podmiejskiej włączenie w struktury wielkiego miasta niosło ze sobą zagrożenia obyczajności. Stąd przykładowo w protokole negocjacji Dąbia [,„Protokół z posiedzenia...” 1905] pojawia się zapis dotyczący zakazu lokalizacji domów rozpusty na dawnym obszarze wsi po włączeniu w granice Krakowa. Z punktu widzenia struktury społeczno-zawodowej ludności nowego, Wielkiego Krakowa problematyczne było więc oprócz opracowania kompromisu w zakresie spraw finansowo-kompetencyjnych także przezwyciężenie uprzedzeń dotyczących mieszkańców łączących się gmin. W nowym organizmie miejskim miał spotkać się - w pewnym uproszczeniu - inteligencki Kraków i rzesze robotników z gmin podmiejskich. Można powiedzieć, że w początkach XX wieku Kraków przeżył podobne zjawisko dotyczące zmiany struktury społecznej, jak to miało miejsce po II wojnie światowej, gdy w jego sąsiedztwie powstała Nowa Huta. Dotychczasowy Kraków, zarówno ten z początków XX wieku, jak i z jego drugiej połowy musiał zmierzyć się z wzajemnymi obawami, niechęcią, nieufnością różnych grup społecznych.

\section{Proces tworzenia Wielkiego Krakowa a współczesne determinanty współpracy w obszarze funkcjonalnym}

Przedstawiona w poprzednim punkcie analiza daje obraz trudności i komplikacji, które wynikły z wieloletniego procesu włączania sąsiednich gmin do 
Krakowa, a później ich adaptacji do struktur miejskich. Różnica stulecia nie skutkuje spadkiem aktualności tych problemów, ponieważ można mówić o pewnej stałości płaszczyzn, na jakich rozbieżności interesów występowały i występują. Zarówno Kraków z początków wieku XX, jak i współczesny to organizmy stanowiące całość funkcjonalną, która wykracza poza granice gminy, tym samym kreując interakcje i zależności pomiędzy gminą rdzeniową a sąsiednimi ${ }^{4}$.

\section{Stan finansów publicznych miasta rdzeniowego i sąsiednich gmin}

W porównaniu danych statystycznych (lata 1902 oraz 2010-2012) dotyczących podstawowych wielkości budżetowych uwidaczniają się znaczące zróżnicowania pomiędzy gminami w zakresie wysokości dochodów budżetowych (zamożności samorządów). Budżet Krakowa początków wieku i współcześnie jest nieporównywalnie większy od budżetów gmin sąsiednich, co jest oczywiste dla wartości bezwzględnych. W przeliczeniu na mieszkańca wyniki z 1902 r. również wskazują jednak na znaczące dysproporcje, choć podkreślić należy odbiegające od innych jednostek wyniki Podgórza. Wartość jego budżetu była równa 14,37\% budżetu Krakowa, ale to poziom zamożności miasta w przeliczeniu na mieszkańca pokazywał siłę zarówno gospodarki ośrodka, jak i jego władz (Kraków osiągnął wynik równy 26,94 kor/os., zaś Podgórze niewiele słabszy rezultat - 19,47). Dziś dysproporcje wielkości bezwzględnych poziomu dochodów są równie znaczące, choć wyniki przeliczone na mieszkańca gminy wskazują porównywalnie mniejsze dysproporcje, jednak z zachowaniem prymatu Krakowa (4539,28 zł/os.) oraz okolicznych gmin miejskich lub miejsko-wiejskich (Skawina, Niepołomice - ponad 3,5 tys. zł/os). Najgorszy wynik pod tym względem uzyskała gmina Kocmyrzów-Luborzyca, jednak jej rezultat (2,4 tys. zł/os.) stanowi ponad 50\% wyniku krakowskiego. Dla porównania w 1912 r. najsłabszy rezultat względny uzyskał Łobzów, którego wynik wynosił nieco powyżej 5\% krakowskiego. Obserwacja ta pozwala na stwierdzenie, że pomimo występowania analogicznych układów dysproporcji dochodowych współczesna sytuacja jest trudniejsza pod względem możliwości wypracowania kompromisu, ponieważ jednostki sąsiadujące z Krakowem są silniejsze finansowo. Jeżeli jednak założyć możliwość osiągnięcia efektywnych płaszczyzn współpracy, to połączone siły miasta rdzeniowego i jego otoczenia dają łącznie lepszy kapitał finansowy do realizacji wspólnych zadań.

\footnotetext{
${ }^{4}$ Krakowski obszar metropolitalny (KOM) obejmuje obecnie powierzchnię 406,5 tys. ha, na której zamieszkiwało na koniec 2011 r. 1,49 mln osób, z czego 759 tys. stanowili mieszkańcy gminy Kraków. Formalnie dla celów statystycznych uznaje się, że KOM tworzy Kraków oraz 50 dalszych gmin [Statystyczne Vademecum Samorzq̨owca 2012... 2013]. W roku 1910 Kraków zwiększył swój potencjał ludnościowy w stosunku do roku 1900 o ponad 57 tys. mieszkańców; według stanu na koniec 1910 r. ludności cywilnej było ponad 142 tys., a ponad 151 tys. wynosiła liczba ludności wraz z wojskiem. Powierzchnia miasta wynosiła 29,62 km² [Kumaniecki 1912]. Przyrost wyniósł około $67 \%$.
} 


\begin{tabular}{|c|c|c|c|c|c|c|c|c|c|c|c|c|}
\hline 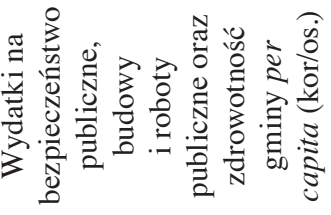 & $\underline{0}$ & $\hat{\sigma}_{0}$ & $\begin{array}{l}\hat{\jmath} \\
\tilde{o}\end{array}$ & İ & $\begin{array}{l}\text { ON } \\
0 \\
0\end{array}$ & o. & $\stackrel{\text { న్ }}{-}$ & $\stackrel{n}{n}$ & $\stackrel{+}{*}$ & 告 & $\begin{array}{l}\overrightarrow{0} \\
0\end{array}$ & $\stackrel{\circ}{0}$ \\
\hline 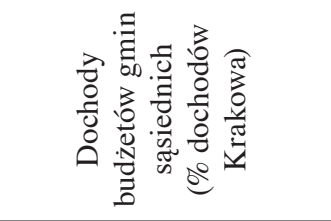 & $\hat{\tilde{o}}$ & 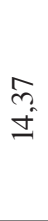 & $\frac{ \pm}{0}$ & $\frac{1}{0}$ & $\stackrel{f}{f}$ & 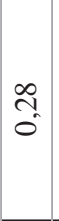 & $\hat{a}$ & $\frac{n}{o}$ & $\begin{array}{l}\tilde{3} \\
\tilde{o}\end{array}$ & 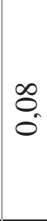 & 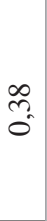 & $\tilde{\sigma}_{0}$ \\
\hline 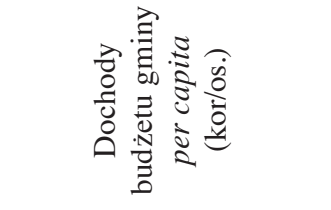 & $\underset{f}{F}$ & $\stackrel{\Im}{\sigma}$ & $\underset{\sigma}{\sigma}$ & $\stackrel{8}{-}$ & $\begin{array}{l}\vec{r} \\
\dot{\sigma}\end{array}$ & 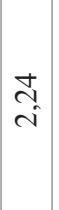 & $\begin{array}{l}\tilde{N} \\
\infty\end{array}$ & $\begin{array}{l}8 \\
0 \\
0\end{array}$ & $\stackrel{m}{\sim}$ & $\underset{\sim}{\stackrel{g}{q}}$ & $\hat{\infty}_{-}$ & बे \\
\hline 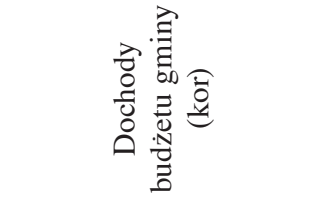 & $\begin{array}{l}0 \\
0 \\
+ \\
\hat{\sigma} \\
\hat{\sigma}\end{array}$ & 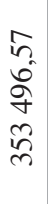 & 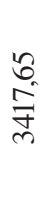 & $\begin{array}{l}\hat{0} \\
\tilde{n} \\
i \delta \\
i\end{array}$ & $\begin{array}{l}\infty \\
\infty \\
i n \\
= \\
=\end{array}$ & $\begin{array}{l}\hat{\sigma} \\
\hat{8} \\
8\end{array}$ & 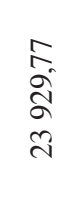 & $\begin{array}{l}0 \\
\stackrel{0}{\circ} \\
\curvearrowleft \\
\infty\end{array}$ & $\begin{array}{l}n \\
\infty \\
\approx \\
n \\
n\end{array}$ & 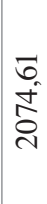 & 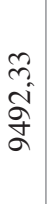 & $\begin{array}{l}\underset{\sim}{d} \\
\infty \\
\infty \\
\infty\end{array}$ \\
\hline 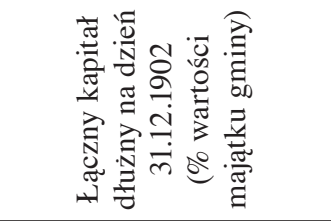 & 8 & $\frac{=}{0}$ & \&. & $\begin{array}{l}n \\
\infty \\
\infty\end{array}$ & $\underset{\Delta}{\stackrel{ \pm}{\Delta}}$ & $\vec{n}$ & $\begin{array}{l}\text { ले } \\
\text { हैं }\end{array}$ & $\begin{array}{l}\text { กิ } \\
\text { กี }\end{array}$ & $\stackrel{8}{8}$ & 8 & \begin{tabular}{l}
0 \\
$\stackrel{n}{\sigma}$ \\
\multirow{\sigma}{*}{}
\end{tabular} & $\approx$ \\
\hline 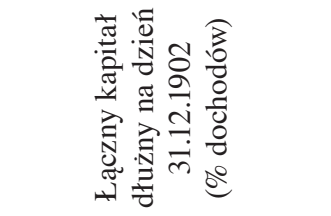 & 8 & $\begin{array}{l}\text { ลे } \\
\text { ลे }\end{array}$ & $\begin{array}{l}8 \\
8 \\
0\end{array}$ & $\frac{\mathbb{N}}{m}$ & $\begin{array}{l}\hat{n} \\
\text { రీ } \\
0\end{array}$ & ָ̃ & $\begin{array}{l}\vec{b} \\
\stackrel{8}{f}\end{array}$ & ๙े & $\begin{array}{l}8 \\
\stackrel{0}{0}\end{array}$ & 8 & $\begin{array}{l}\infty \\
\infty \\
\infty \\
\infty \\
\tilde{n}\end{array}$ & $\begin{array}{l}8 \\
8 \\
0\end{array}$ \\
\hline 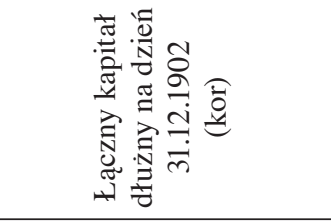 & 8 & $\begin{array}{l}\infty \\
\infty \\
\infty \\
\delta \\
\infty \\
\infty \\
0\end{array}$ & 8. & $\begin{array}{l}8 \\
0 \\
\stackrel{8}{a}\end{array}$ & $\begin{array}{l}n \\
\text { đi } \\
\curvearrowleft \\
2\end{array}$ & 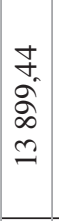 & 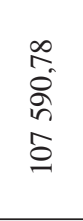 & $\begin{array}{l}\hat{n} \\
\text { ñ } \\
n \\
n \\
n\end{array}$ & $\begin{array}{l}8 \\
8\end{array}$ & 8 & 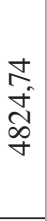 & 8 \\
\hline & 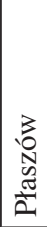 & 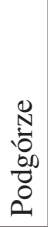 & 告 & 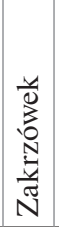 & 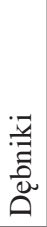 & 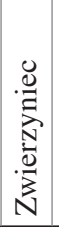 & 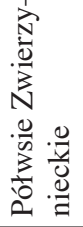 & 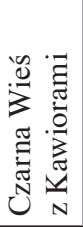 & 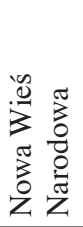 & $\begin{array}{l}3 \\
3 \\
0 \\
0 \\
0 \\
+1 \\
1\end{array}$ & 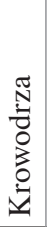 & 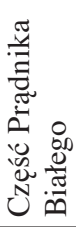 \\
\hline
\end{tabular}




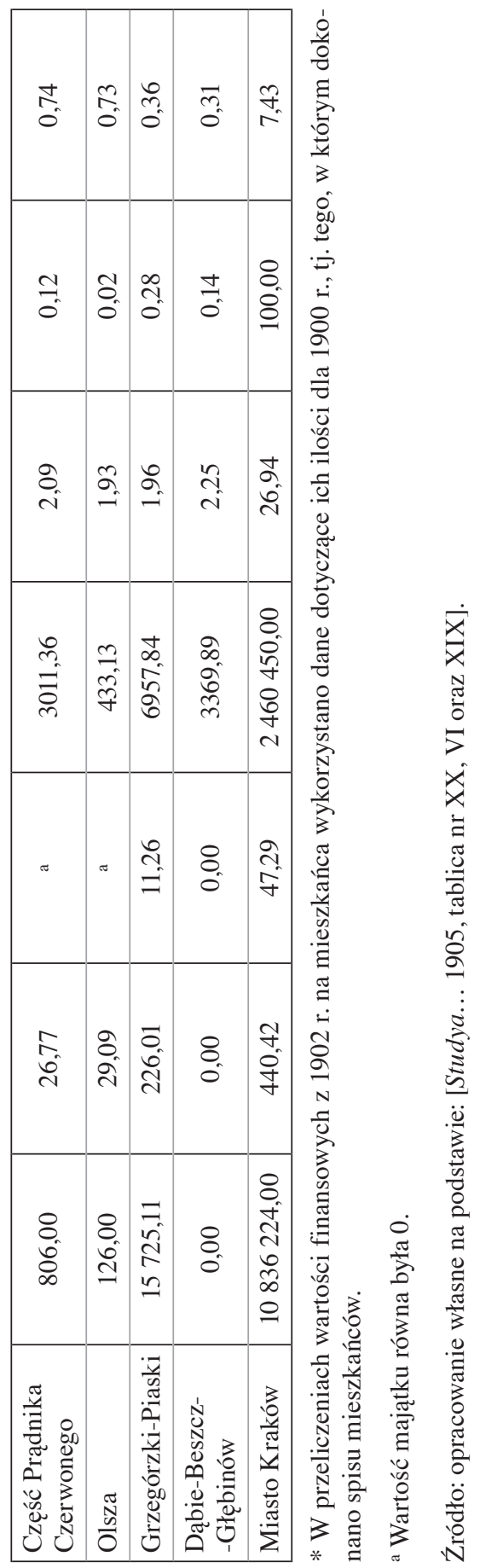




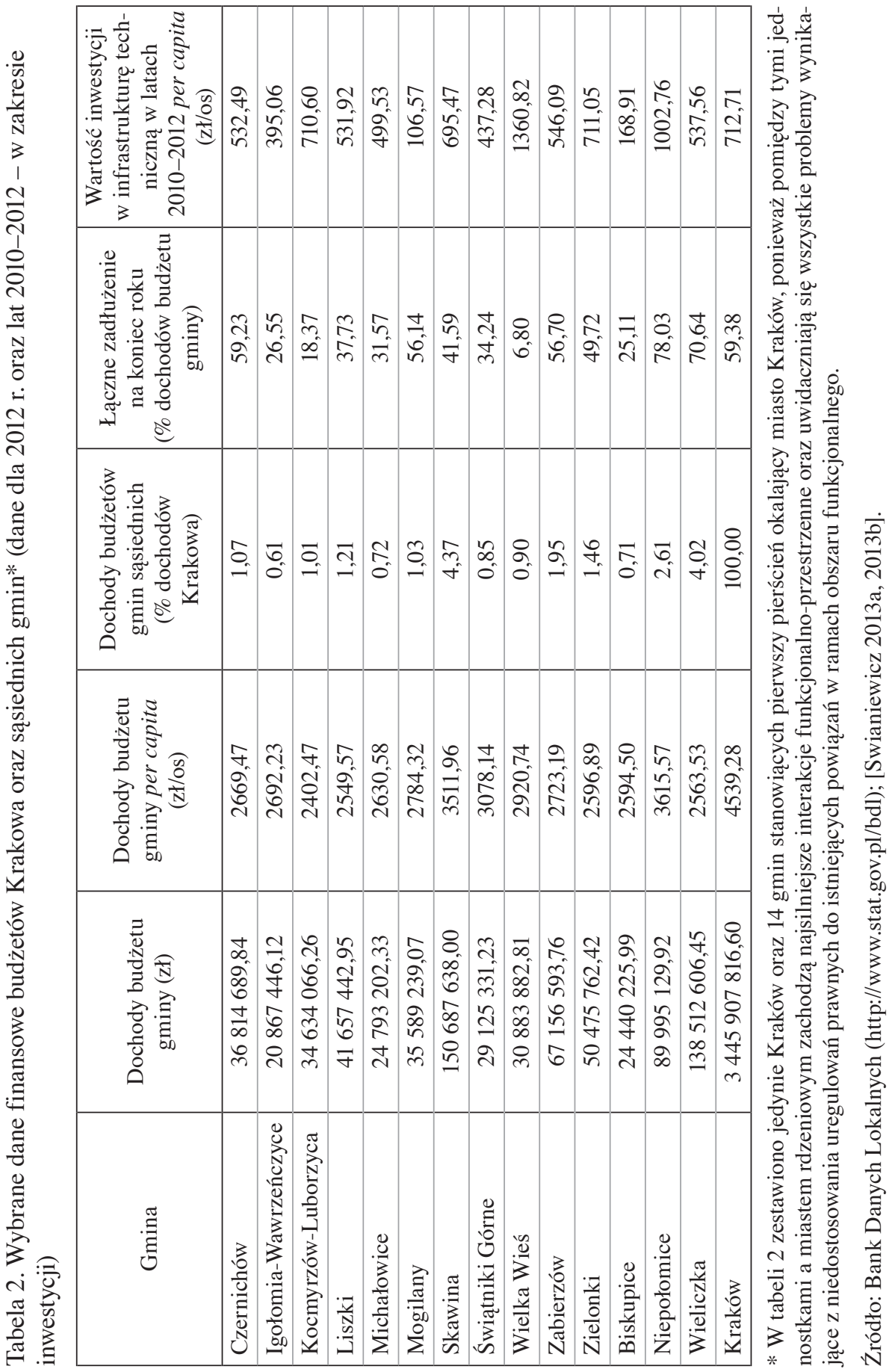


Oceniając możliwości finansowe dla efektywnej współpracy, należy zwrócić uwagę na zadania już realizowane indywidualnie w gminach. Okazuje się bowiem, że gminy początków XX wieku były słabsze finansowo i mniej aktywne. W 1902 r. poziom inwestycji infrastrukturalnych per capita dla Krakowa był nieco wyższy od tego osiągniętego przez Podgórze, znacząco zaś wyższy niż w pozostałych gminach (z wyjątkiem Czarnej Wsi oraz Półwsia Zwierzynieckiego, z rezultatami odpowiednio równymi 34\% i 24,4\% wyniku Krakowa). Dzisiejsze jednostki sąsiadujące z miastem osiągają wyniki względne niekiedy lepsze niż miasto rdzeniowe (np. Wielka Wieś czy Niepołomice). Niezmienny pozostaje jednak fakt, że ich polityka inwestycyjna realizowana jest w oderwaniu od kryterium racjonalności rozpatrywanej w kontekście całego obszaru funkcjonalnego. Dysproporcje istniejące 100 lat temu w zakresie wielkości budżetów przekładały się na zróżnicowanie poziomu zadłużenia gmin. W 1902 r. gminy bardziej zamożne zadłużały się intensywniej, te o słabym potencjale dochodowym i małej wartości majątku niekiedy w ogóle nie zaciągały tytułów dłużnych. Współcześnie (z wyjątkiem Wielkiej Wsi) poziom zadłużenia w stosunku do dochodów osiąga rezultat dwucyfrowy, z najwyższym wynikiem dla Niepołomic i Wieliczki. Samorządy ościenne są więc dziś bardziej przysposobione siłą swoich dochodów do inwestowania, m.in. również poprzez możliwość zadłużania się. W obu punktach czasowych ukierunkowanie inwestycji niekoniecznie było jednak zgodne z długookresową racjonalnością rozwoju obszaru funkcjonalnego, zaś istniejący już poziom zadłużenia zarówno Krakowa, jak i wielu gmin ościennych każe sądzić, że znacząco wykorzystały już one rezerwy finansowe na inwestycje. Tym samym uwidacznia się koszt upływu czasu w procesie wdrażania rozwiązań dostosowawczych struktur administracyjnych. Jeżeli bowiem nawet teraz wprowadziłoby się pewne rozwiązanie dostosowawcze, to budżety jednostek tworzących nową strukturę wykazywać się będą malejącą możliwością kapitałochłonnych działań.

Analiza danych statystycznych wskazuje, że choć specyfika problemów na linii Kraków-gminy ościenne jest analogiczna jak w początkach XX wieku, ich natężenie jest większe i tym samym możliwości poszukiwania efektywnych sposobów współpracy mniejsze. Gminy są dziś silniejsze finansowo, a tym samym odważniejsze w prowadzonej polityce inwestycyjnej. Ta zaś opiera się na polityce rozwojowej dostosowanej do potrzeb danej jednostki w jej granicach, bez uwzględniania terenów sąsiednich.

\section{Przestrzenno-gospodarcze uwarunkowania funkcjonowania obszarów rdze- niowych i okołomiejskich}

Przedstawiona sytuacja dotyczy zarówno działań strategicznych, jak i polityki przestrzennej. Istniejące uwarunkowania prawne, które zlikwidowały mechanizmy uspójniania polityki przestrzennej (w tym w obszarach metropolitalnych), 
prowadzą do niekorzystnych decyzji, utrudniających funkcjonowanie miasta rdzeniowego (likwidacja rezerw pod inwestycje obwodnicowe ${ }^{5}$, klinów napowietrzania miasta itp.). Kraków uzależniony jest tym samym od działań czy inwestycji mających miejsce poza jego granicami. Nawet tak kluczowe dla współczesnej metropolii kwestie jak skomunikowanie lotnicze rozgrywają się poza Krakowem zarówno w wymiarze podmiotowym, jak i przestrzennym ${ }^{6}$. Kiedyś analogiczna kwestia dotyczyła planowanej budowy kanału Odra-Dunaj.

Porównując występujące przesunięcia przestrzenne osób i podmiotów gospodarczych pomiędzy rdzeniem a gminami sąsiednimi, widzimy kolejne analogie. Tak jak kiedyś w otoczeniu miasta poszukiwano możliwości zmniejszenia kosztów życia czy funkcjonowania, tak i dziś sytuacja przedstawia podobne uwarunkowania i kierunki migracji. Krakowianie przenoszą się na obszary podmiejskie, gdzie działki budowlane są znacznie tańsze niż w mieście, firmy zaś dodatkowo (oprócz niższych kosztów) mogą liczyć na większe zaangażowanie samorządów lokalnych w zakresie tworzenia warunków ich funkcjonowania. Zachowane zostają możliwości korzystania z wszystkich dogodności sąsiedztwa wielkiego miasta. Zjawisko migracji znajduje odbicie w poziomie nasycenia przestrzeni wokół Krakowa podmiotami gospodarczymi na 1 tys. mieszkańców w powiatach sąsiadujących z miastem ${ }^{8}$.

Odnosząc się do różnych form utraty części swobody funkcjonowania w obecnie istniejących gminach, należy zaznaczyć - z obserwacji już ponad 20-letniej historii działania odrodzonych samorządów w Polsce - że ich siła wyraża się nie tylko w lepszej niż 100 lat temu sytuacji finansowej. Samorządność i niezależność z nią związana są wartością samą w sobie, w pewnym sensie symboliczną, wyrażającą się dziś także poprzez odzyskaną czy wykreowaną silną tożsamość lokalną okolicznych społeczności. Niekiedy bywa ona także związana z konkretnymi spośród lokalnych polityków, dzięki którym odnoszone są spekta-

${ }^{5}$ Zaznaczyć należy jednak, że likwidacja tych rezerw w jednostkach ościennych jest także wyrazem z jednej strony chęci rozwoju zagospodarowania w gminach, a z drugiej strony bezsilności wynikającej z opieszałości działań podmiotów odpowiedzialnych za realizację infrastruktury - przykładem jest sprawa przebiegu północnej obwodnicy Krakowa m.in. przez gminę Zielonki.

${ }^{6}$ Port Lotniczy obsługujący m.in. Kraków zlokalizowany jest w Balicach. Samorząd ma znikomy udział w spółce zarządzającej portem.

7 W roku 2012 w powiatach: wielickim, krakowskim i myślenickim oddano do użytkowania 3154 mieszkania i 2870 budynków, a w Krakowie odpowiednio 8262 i 923 (Bank Danych Lokalnych http://www.stat.gov.pl/bdl).

${ }^{8}$ Wszystkie powiaty sąsiadujące $\mathrm{z}$ Krakowem osiągnęły rezultat nasycenia podmiotami gospodarczymi w przedziale 10-20 podmiotów/1 tys. mieszkańców [„,Województwo małopolskie 2012” 2012, s. 123, 154]. 
kularne sukcesy rozwojowe ${ }^{9} . \mathrm{Z}$ drugiej strony nowi mieszkańcy gmin ościennych wciąż w sferze meldunkowej często pozostają krakowianami, co jest chyba najlepszym dowodem na powiązania i zależności przestrzenne, w których Kraków nie kończy się na granicach administracyjnych.

\section{Podsumowanie}

Historia urbanistyki wiąże rozwój miast z czynnikami społecznymi, politycznymi i gospodarczymi determinującymi możliwości i potencjał rozwojowy ośrodków, wskazując rozmaite drogi rozwiązywania problemów niedostosowania funkcjonalno-przestrzennego do struktur administracyjnych. Organizmy miejskie i rozlewająca się wokół nich zabudowa na różny sposób włączane były w granice miast rdzeniowych, nawet jeżeli pierwotnie stanowiły odrębną jednostkę (np. tzw. „,nowe miasta” tworzone od czasów średniowiecznych lokacji, które po powstaniu były inkorporowane przez ośrodek rdzeniowy). Wzorce przełomu wieków XIX i XX wskazują na dostosowania polegające na wchłanianiu mniejszych jednostek, niekiedy jednak o stosunkowo dużym znaczeniu (np. Podgórze). We współczesnych uwarunkowaniach w praktyce rozwiązywania analogicznych problemów usiłuje się zachowywać autonomię jednostek i tworzyć tzw. „lekkie struktury” organizacyjno-prawne. Przedstawiona w niniejszym artykule problematyka obrazuje trudność i stopień skomplikowania zależności pomiędzy rdzeniem obszaru funkcjonalnego a jego peryferiami. Analizowany przykład wskazuje też jednoznacznie, że problem ma charakter stały, choć zmieniają się jego szczegółowe uwarunkowania. Dlatego też bezsprzeczny pozostaje fakt, że konieczne jest prowadzenie procesów dostosowawczych w systemie kroczącym, tak aby rozdzielone granicami administracyjnymi związki funkcjonalne mogły jak najintensywniej się rozwijać oraz aby ograniczane były negatywne oddziaływania o charakterze partykularnym. Podjęcie we właściwym czasie skutecznych działań w tym zakresie pozwala na ograniczenie ,pasożytniczych” form oddziaływania na korzyść interakcji obustronnie korzystnych dla zaangażowanych we współpracę jednostek. Zależność tę słusznie zauważono w „Sprawozdaniu Komisji Gminnej o Sprawozdaniu Wydziału Krajowego w przedmiocie połączenia gmin i obszarów dworskich do Miasta Krakowa” [1908]. Zapisano tam, że choć „(...) wśród dyskusji publicznej (...) dla scharakteryzowania stosunku uboższych gmin do zamożniejszego Krakowa, odwołano się do analogii świata zwierzęcego i mówiono o pasożycie, ciągnącym soki żywotne z obcego organizmu, to zaznaczyć należy, że

${ }^{9}$ Można w tym miejscu przywołać chociażby przykład podkrakowskich Niepołomic i ich wieloletniego burmistrza - Stanisława Kracika. W wyniku swoich działań przyciągnął on licznych dużych inwestorów, którzy wybrali Niepołomice, a nie Kraków na swoją siedzibę. 
byłoby daleko właściwiej na analogię świata roślinnego się powołać, tego świata, który zna «symbiozę», tj. współżycie dwóch istot, które nie łącząc się fizycznie, obok siebie rosną, chroniąc się i wzajemnie pomagając".

W rozszerzeniu granic upatrywano realizację naturalnej konsekwencji rozwoju, która przy odpowiedniej organizacji przyniesie długofalowe pozytywne skutki dla całego obszaru. W tym wymiarze realizacja postulatu wykreowania miejskiej przestrzeni, w której mieszkańcy mają odpowiednią do swoich potrzeb dostępność „miejsca, światła i powietrza” [Przeorski 1931, s. 624], stała się determinantą działania ówczesnych władz, pozostając dalej aktualną i w uwarunkowaniach współczesnych. Pomimo szeregu trudności, konfliktów, jakie towarzyszyły procesowi powstawania Wielkiego Krakowa, po upływie wieku można jednoznacznie stwierdzić, że był to proces konieczny, w którym dobro jednostkowe musiało zostać podporządkowane dobru całości funkcjonalnej. Wydaje się więc, że kluczowe dla zrozumienia istoty złożonego problemu poruszonego w niniejszym artykule jest pogodzenie się z koniecznością zastosowania pewnej formy „utraty wolności” na rzecz większej racjonalności. To z kolei wymaga poszukiwania kompromisu, który musi zostać osiągnięty w indywidualnie dopasowanych rozwiązaniach dla danego zestawu łączących się w danym wymiarze jednostek.

\section{Literatura}

Bank Danych Lokalnych, http://www.stat.gov.pl/bdl.

Bąkowski K. [1905], Sprawa rozszerzenia granic Krakowa, odbitka z „Głosu Narodu”, Kraków.

„Biała księga obszarów metropolitalnych” [2013], Ministerstwo Administracji i Cyfryzacji, Warszawa.

Bober J. i in. [2013], Narastajqce dysfunkcje, zasadnicze dylematy, konieczne dziatania. Raport o stanie samorzq̨ności terytorialnej w Polsce, MSAP, Kraków.

Izdebski H. [2012], Dylematy ustawy metropolitalnej, referat wygłoszony na konferencji „Polskie metropolie - dokonania i kierunki rozwoju”, Poznań.

„Koncepcja przestrzennego zagospodarowania kraju 2030” [2011], dokument przyjęty przez Radę Ministrów 13.12.2011, Ministerstwo Rozwoju Regionalnego, Warszawa.

Kraków. Rozszerzenie granic. 1909-1915 [1931], red. K. Rolle, nakładem Gminy Stołecznego Miasta Krakowa, Kraków.

Kumaniecki K.W. [1912], Tymczasowe wyniki spisu ludności w Krakowie z 31 grudnia 1910 r., nakładem Gminy Miasta Krakowa, Kraków.

„Protokół z posiedzenia Rady Gminnej w Dąbiu” z 25.02.1905.

„Protokół z posiedzenia Rady Gminnej w Dębnikach” z 17.03.1904.

„Protokół z posiedzenia Rady Gminnej w Ludwinowie” z 14.03.1904.

„Protokół z posiedzenia Rady Gminnej w Łobzowie” z 26.03.1904.

„Protokół z posiedzenia Rady Gminnej w Półwsiu Zwierzynieckim” z 28.03.1904.

„Protokół z posiedzenia Rady Gminnej w Zakrzówku” z 20.04.1904. 
Przeorski T. [1931], Rozszerzenie granic Stołecznego Królewskiego Miasta Krakowa w latach 1909-1915 [w:] Kraków. Rozszerzenie granic. 1909-1915, red. K. Rolle, nakładem Gminy Stołecznego Miasta Krakowa, Kraków.

Slack E. [2007], The Role of Metropolitan Governance [w:] Managing the Coordination of Service Delivery in Metropolitan Cities, Policy Research Working Paper 4317, The World Bank, Urban Development Unit.

Smętkowski M., Jałowiecki B., Gorzelak G. [2008], Obszary metropolitalne w Polsce: problemy rozwojowe i delimitacja, Raporty i Analizy - Euroreg 1/2009, Warszawa.

„Sprawozdanie Komisji Gminnej o Sprawozdaniu Wydziału Krajowego w przedmiocie połączenia gmin i obszarów dworskich do Miasta Krakowa”, Ls. 2.951/1908, Lwów, 26.10.1908.

„Sprawozdanie Komisyi Rady Miasta Podgórza delegowanej do zbadania warunków połączenia Podgórza z Krakowem z przebiegu przeprowadzonych dotychczas pertraktacji z gminą Miasta Krakowa” [1913], nakładem Gminy Miasta Podgórza, Podgórze.

„Sprawozdanie stenograficzne z rozpraw galicyjskiego Sejmu Krajowego 34 posiedzenia I Sesji IX Perjodu" z dnia 3.11.1908.

„Sprawozdanie Wydziału Krajowego w przedmiocie przyłączenia sąsiednich gmin i obszarów dworskich do miasta Krakowa” (LW.95.195/1907), Lwów, 27.09.1907.

Statystyczne Vademecum Samorzqdowca 2012 - Krakowski Obszar Metropolitalny [2013], Urząd Statystyczny w Krakowie, http://www.stat.gov.pl/vademecum/vademecum_malopolskie/portret_obszaru_metropolitalnego/krakowski_obszar_metropolitalny.pdf (dostęp: 19.08.2013).

Studya do sprawy przyłaczenia gmin sqsiednich do miasta Krakowa [1905], nakładem Gminy Miasta Krakowa, Kraków.

Swianiewicz P. [2013a], Ranking gmin wedtug wydatków na infrastrukturę technicznq w latach 2010-2012, Pismo samorządu terytorialnego „Wspólnota”, nr 21/2013 z 12 października.

Swianiewicz P. [2013b], Ranking - Najbogatsze samorzqdy 2012, Pismo samorządu terytorialnego „Wspólnota”, nr 14/2013 z 6 lipca.

„Województwo małopolskie 2012” [2012], Departament Polityki Regionalnej, Urząd Marszałkowski Województwa Małopolskiego, Kraków.

„Założenia krajowej polityki miejskiej do roku 2020” [2013], dokument przyjęty przez Radę Ministrów w dniu 16 lipca 2013 r., Ministerstwo Rozwoju Regionalnego, Warszawa.

„Zielona księga dotycząca obszarów metropolitalnych” [2012], Ministerstwo Administracji i Cyfryzacji, Warszawa.

Serwis statystyczny „StatKrak”, http://msip2.um.krakow.pl/statkrak/view/show/view10. asp?tab=k_lud_stan_ruch_naturalny_v1\&rok=2012\&wyniki=Wyniki (dostęp: 19.08.2013).

\section{The Economic and Social Determinants of the Effectiveness of Local Government Structures in Adjusting to Their Functional Areas - the Example of Cracow in the Early Twentieth Century}

This paper analyses the conditions for municipal self-government structures adjusting to the requirements of the growing urbanised area around Cracow in the early twentieth 
century. In the survey of historical sources, the determinants of the success of this process were sought. The then and current situations of local governments comprising the metropolitan area were also compared, with clear similarities and certain differences becoming evident. The differences arose from: the greater prosperity of neighbouring communities, a higher level of local identity, and the spectacular success of local governments such as investment policy or attracting strategic investors. All this suggests that future adjustment processes will be extremely difficult to implement in a form that will ensure their effectiveness.

Keywords: functional area, metropolitan area, Cracow, local municipality. 